\title{
Influence of Government Policy on Highland Agriculture Development in Enrekang Regency, South Sulawesi, Indonesia
}

\author{
Idris Summase*, M. Saleh S. Ali, Darmawan Salman, Didi Rukmana \\ Department of Agricultural Socio-economics, Universitas Hasanuddin \\ *Corresponding author's e-mail: idrissummase@yahoo.co.id
}

How to Cite: Sumase, I., Ali, M.S.S., Salman, D., and Rukmana, D. (2019). Influence of Government Policy on Highland Agriculture Development in Enrekang Regency, South Sulawesi, Indonesia. Int. J. Agr. Syst. 7(2): 100-105

\begin{abstract}
Upland agriculture faces threats in the ecological crisis that will affect the sustainability of highland communities. The process lasts quite long because of external and internal influences, leading to ecological exploitation. Agricultural development, is closely related to the influence of government policy. Research focuses on discussing aspects of policy influence on the development of upland agriculture. The research is a qualitative study, using an inductive approach, the case of ethnic thorn communities in Enrekang Regency. The results of the study indicate that the three main policies that influence the development of upland agriculture are: 1). Political policy and government system, 2). Rural development policies and infrastructure, 3). Decentralization or regional autonomy, 4). Economic policies, especially investment and markets. The conclusion is that the development of agriculture is economically progressing in the shadow of the ecological crisis, drought, flooding and impact on humanitarian crisis, because it needs arrangements in land management and the application of technology for agricultural development.
\end{abstract}

Copyright $\odot 2019$ IJAS. All rights reserved.

Keywords:

Highland agriculture; ecological crisis; policy

\section{Introduction}

Sulawesi Island is the fourth largest island in Indonesia after Kalimantan, Sumatra and Papua (Watuseke, F. S. 1974). The land area is $180,680.7 \mathrm{~km} 2$, mostly mountainous above an altitude of 500 meters above sea level (masl) with a distribution in the middle extending from the south to the north and flanked by the west and east coastal areas. Mount Latimojong is the highest mountain (3,680 masl) located in Enrekang Regency, South Sulawesi Province.

In the latimojong mountain region there are indigenous tribes, namely the tribe of Bugis, Toraja, Mandar, and Massenrempulu. Toraja and massenupempulu tribes inhabit the highlands, work as farmers and utilize forest products for trade (Crawfurd, 1986). The ethnic groups occupied the Enrekang regency, in the XVII century joined to make an alliance into a large kingdom called Malempong Bulan spread in seven regions called the Pitu massenrempulu, namely: Endekang, Kassa, Lappa, Duri, Maiwa, Letta, and Beringin. In 1905, the Dutch government established a decree (korte Verklaring), namely the kingdom of Kassa and Batu lappa, which was entered into the 
kingdom of Sawitto, one kingdom centered on the western coast of South Sulawesi, so that the kingdom of massenrempulu berkuran into five kingdoms.

The Massenrempulu tribe like other archipelago tribes have experienced various currents of cultural influences Hinduism, Buddhism and Islam (Miksic, 1996) forming a large tradition (Redfield, 1956) fused with local animist beliefs in a rich syncretic mixture (Geertz, 1960) forming the aluk to tradition jolo.

The development of mass ethnic groups, closely related to the influence of the ruling government from Dutch colonialism until independence on August 17, 1945 formed the government of the Republic of Indonesia which has provided three types of policy in Indonesia, namely: the new order, the old order, and the post-new order government.

Various policies have influenced the large-scale community living from highland agricultural activities, have influenced the development of agriculture, the social system and the mass ethnic ecology of the first. This paper focuses on discussing aspects of policy influence on the development of upland agriculture.

\section{Materials and Methods}

The study was a qualitative study, using an inductive approach, in the case of the indigenous ethnic masenrempulu people, namely ethnic duri residing in the Enrekang highlands above 1750 meters above sea level (masl), namely the Baroko Subdistrict, Enrekang district. The rationale for research is the system approach developed by Rambo (1984), adapted according to the research objectives as follows.

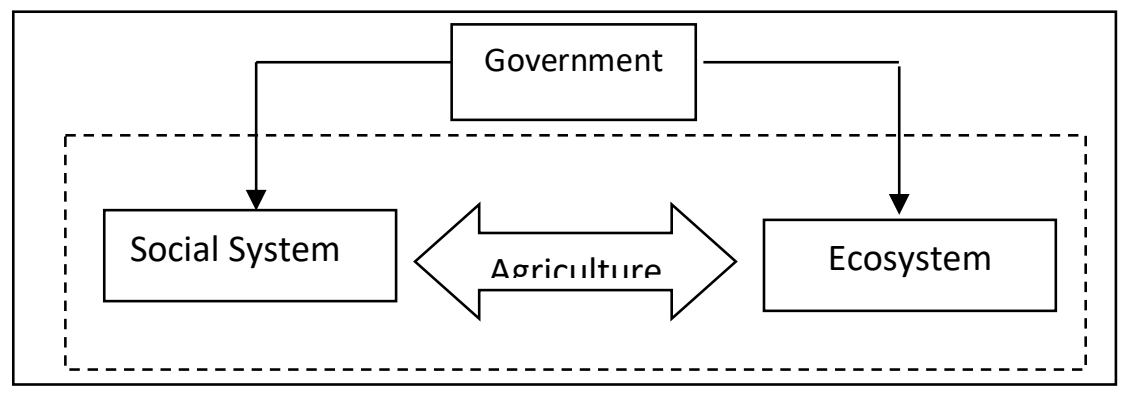

Figure 1: Research Thinking Framework

Data was collected using the focus group discussion method / FGD in-depth interview and documentation study. The unit of analysis is agricultural activities in the farming community of the Baroko highland ecosystem. The important aspects studied are policies (investment, technology, infrastructure, regulation, people's participation, and authority); ecosystem dynamics (water, land, climate, animals and plants); the dynamics of social systems (population, value systems, social institutions, markets, technology); and agricultural development (Agricultural systems: technology, markets, commodities, and production processes). The analytical methods used in the study are: Descriptive Analysis, Historical Analysis and Content Analysis. 


\section{Results and Discussion}

\subsection{Highlands Ecosystem}

Located at the coordinates of $3^{\circ} 14^{\prime} 3$ "South Latitude (LS) to $3^{\circ} 50$ '00" LS and 119² $40^{\prime} 53$ "East Longitude (BT) to $120^{\circ} 06^{\prime} 33^{\prime \prime}$ BT. The geographical form of mountains and hills is $+85 \%$ (470 meters to 3,329 meters above sea level) of an area of 1,786.01 $\mathrm{Km}^{2}$. Regional boundaries: north of Tana Toraja Regency, east of Luwu Regency, South of Sidenreng Rappang Regency, and Pinrang Regency. Water conditions, in accordance with the hydrological cycle of the Latimojong mountainous region, are central to the surrounding lowland waters, namely: Pinrang Regency, Sidenreng Rappang, Wajo, and Luwu. The condition of the water is influenced by the extent of the catchment area. The water catchment areas include Polewali District, Mamasa Regency, and Tana Toraja with the Saddang watershed, and water catchments in Engrekang District forming sub-watersheds, namely: Enrekang, Bungin, Cendana, Baraka, and Maiwa. The Saddang watershed controls its water through the Benteng Dam to determine irrigation in Pinrang and Sidenreng Rappang Regencies. When the watershed with Bulu Cenrana irrigation in Sidenreng Rappang district. Climate situation, based on rainfall data, temperature and precipitation refers to rainfall data / $\mathrm{CH} 17$ years (Year period, 2001-2017), has a high $\mathrm{CH}$ with an average of $2350 \mathrm{~mm}$ per year and average rainy days / HH 128 days per year. $\mathrm{CH}$ monthly highest December and lowest August. Climate type in Enrekang, namely Maiwa and sandalwood climate type C1 Kalosi type E1, and Baraka type D1. For Flora and Fauna, in Enrekang Regency include bitti trees or commonly called vitexcofassus, Sulawesi black trees (diospyros celebica), ulin / ironwood (eusideraxylonzwageri), lithocarpus celebica trees, spinach wood, agatis wood (agatis celebica), yellow wood (arcangelisia flava merr), rattan lambing (calamus $\mathrm{sp}$ ), and rattan tohiti (calamus inops becc). The main annual crops cultivated are: Coffee, Cocoa, Cloves, Candlenut, Coconut, Pepper, Vanilla Salak, Breadfruit, Jackfruit, Durian, Pewpaya, Banana, Rambutan, Pineapple, and Palm Sugar. Sdang musisman plants, namely: vegetables (Kooll, Chili, Tomatoes, Potatoes, Shallots, Red Onions, and nuts), Cassava, Sweet Potatoes, Rice and Corn. Animals that are often found such as Pigs, and livestock that are mostly maintained and cultivated are: Buffalo, Cow, Horse, Goat, and Chicken.

\subsection{Highlands Ecosystem}

In the XIV Century, Enrekang Regency was a large kingdom called Malepong Bulan, consisting of 7 regions (Pitu Massenrempulu), namely: Endekan, Kassa, Batu Lappa, Duri, Maiwa, Letta, Baringin. The XVII century became five after the kingdom of Kassa and Batu Lappa joined the kingdom of Sawitto on the basis of a Decree of the Royal Dutch Order (Korte Verklaring). The kingdom of Massenrempulu became a landshap led by an Arung assisted by Sulewatang and Pabbicara, Arung Lili, but the policy remained in the hands of the Dutch control. In 1912 it changed to "Onder Afdeling" Japanese Occupation (1941-1945) changed to Enrekang cannabis, NICA Age (NIT 1946 - December 27, 1949) became Onder Afdeling Enrekang. From December 27, 1949 to 1960 the Massenrempulu area was changed to Kewedanaan Enrekang, then changed to the Swantara Region (DASWATI II) of Massenrempulu Regency, then became the District of Dati II Enrekang. Enrekang Regency consists of 5 Districts, namely: Enrekang, Maiwa, Anggeraja, Baraka, and Alla. After the 1998 reforms, Enrekang District has 12 sub-districts, namely: Enrekang, Maiwa, Anggeraja, Baraka, Alla, Curio, Bungin, Malua, Cendana, Buntu Batu, Masalle, Baroko. Enrekang District Government 
territory consists of 12 sub-district administrative regions, 112 villages and 17 subdistricts, 457. Hamlets. In terms of demographic conditions, the population of Enrekang Regency grew by 0.8 percent per year, with a density of 112.9 people / km2 (in 2016). The highland area has a higher density: the Alla sub-district with a density of 640.5 inhabitants, and the Baroko area 257.6 people $/ \mathrm{km}$. Experienced economic growth during the 2012-2016 period showing an increase in 2012 growth with a figure of around $5.30 \%-7.24 \%$. The economic structure, the agricultural sector is still quite dominant with an average still above $45 \%$. There are 13 types of agricultural commodities that are traded consisting of: Rice, Corn, Shallot, Cocoa, Tomato, Broiler, Dairy Cow, Broiler, Domestic Chicken, Pecan, Coffee, Cocoa, Pepper, and Cloves.

Opportunities that can be developed are the agricultural industry sector, namely processing: shallots, tomatoes, koll, broiler and dairy cows, coffee, cocoa, cloves, pepper and sugar palm, and potatoes. Agricultural conditions are indicated by land use, in Enrekang district for settlement, agriculture, plantations and forests. The former highland agriculture was subsistence agriculture with the production of taro staple food, corn banana, and barre (local rice). Coffee plantations, buffalo and horse farms, pond fisheries by cultivating tilapia. Various policies have led to changes so that subsistence agriculture leads to commercial agriculture, so that the agriculture cultivated by residents is coffee, vegetables (cabbage and tomatoes). Agricultural practices with input systems that are minimal with motive to meet needs have long been practiced, replaced with technology with new varieties imported from outside the village) with capital (fertilizers, pesticides and medicines). Agriculture with a consumption motive develops towards the fulfillment of commercially oriented rural markets that encourage production with cultivation practices that threaten ecology, namely dryness, contamination of pesticides and chemical fertilizers that can make the land in a condition of degrading functions.

\subsection{Government Policy in the Highlands}

Government policies before the New Order related to the political system that brought changes in the local political system, caused intrigue of power struggles which had the effect of carrying out security operations in the Baroko area to isolate concentrated settlements, resulting in neglect of coffee plantations so that both production and markets were stopped for 7 years. The new order with political recovery and agricultural development introduces agricultural technology based on fertilizers and pesticides, has encouraged market-oriented agricultural activities by selecting commodities needed by the market, expanding areas accompanied by the destruction of natural systems (forests), as a strategy for increasing production. Improving market institutions and supporting road infrastructure has led to an increase in rural agricultural markets and production, followed by increasing new needs to encourage increased commercial production.

The policy of road infrastructure development has encouraged the interaction of farmers as producers to expand the market and the emergence of new rural professions as agricultural entrepreneurs engaged in marketing agricultural products, thus forming new ties between producers and entrepreneurs both as trading partners, as well as investors that lead to permanent ties. The policy of regional autonomy and village autonomy has brought major changes in the development of road networks and the opening up of outside village investment into the village has an impact on highland 
agricultural activities that are more intensive with the use of technology that neglects aspects of ecological sustainability:

1. Effect of technology on highland agricultural activities. The technology that is important in the development of highland agricultural activities can be identified types and effects as follows.

a) The technology of fertilizers and pesticides has brought great changes both in terms of extensification and intensification of agricultural vegetable crops or seasonal crops,

b) Transportation technology (roads and motorized four-wheeled vehicles and two-wheeled vehicles) has pushed the agricultural commodity market in bulk, encouraging demand and high-yield agricultural production activities, especially vegetables.

c) Communication technology has driven the vast network of commodity markets from vegetable highland crops and coffee.

d) The processing technology for coffee plants has an effect on post-harvest which is better, because of the choice of farmers in selling desired products and strengthening farmers' strength in pricing.

e) Technological developments have impacted on vegetable production activities which do not refer to climate and rainy season, but production activities refer to harvest time.

2. The influence of the market on highland agricultural activities, identified the impact on agricultural activities as follows.

a) The development of the agricultural market is not dependent on conventional market transactions, but trade transactions take place through the use of communication media and facilitation of financial transactions. As a result, large traders and collectors concentrate on the availability of production. Traders are involved in production supervision to ensure availability of supplies to partners.

b) Increasing demand drives intensive production and cropping land into important production and steps in the highlands.

Regarding policies, technology and markets in agriculture, the community has a production adaptation strategy and consumption as follows:

1 The adaptation strategy of farmers' production is to conduct intensification and use of fertilizer and pesticide technology to secure production or supply, use technology, dew, pump and sprinkle water to overcome the problems of plant water needs, to do extreme slope expansion with bench terrace technology from stone. For coffee plantations to process products to increase value added to better prices.

2 Community consumption strategy, namely staple rice all purchased from outside the village, consumption of fish, eggs and tofu purchased by utilizing the services of peddlers from outside the village, vegetables for consumption are mostly obtained from peddlers (pa'gandeng). 


\subsection{Agricultural Development: Forestry and Plantation}

Forest resources are one of the life supports that must be managed wisely in order to be able to provide contributions and benefits optimally and sustainably. The development of forests in the highlands is threatened by sustainability because conversion into vegetable land for commercial purposes. Now forests are generally planted with low density trees (rare) and overgrown with shrubs like shrubs. The ecological function in its development is damaged. In general, the area of plantation in Enrekang Regency experienced a decline, but production increased. The decline in plantation area is high due to the conversion of plantation land to vegetable crops. The main factor is higher vegetable farming income due to intensive efforts to use land, densely populated people in the highlands with scarcity of land become one of the factors that exploit crops that provide high income.

\section{Conclusion}

The three main policies that influence the development of upland agriculture are: 1). Political policy and government system, 2). Rural development policies and infrastructure, 3). Decentralization or regional autonomy, 4). Economic policies, especially investment and markets. The development of agriculture is economically progressing in the shadow of the ecological crisis, drought, flooding and impacts on humanitarian crisis. Therefore, it is necessary to regulate land management and the application of technology for agricultural development, and limit the increase in street area to extreme fraud, because it affects land conversion.

\section{References}

Anderson, J. N. (1974). Ecological Anthropology. Handbook of Social and Cultural Anthropology.

Clifford Geertz (1968). Agricultural Involution: The Process of Ecological Change in Indonesia. Berkeley: University of California Press.

Colfer, C . J . P. (1981). Women, men, and time in the forests of East Kalimantan. Borneo Research Bulletin 13(2):75-85.

Colinvaux, P. A. (1973). Introduction lo Ecology. New York: John Wiley and Sons.

Durkheim, E. (1915) The Elementary Forms of Religious Life. London: G. Allen and Unwin, Ltd.

Firth, R. (1936). We, the Tikopia: A Sociological Study of Kinshop in Primitive Polynesia. London: G. Allen and Unwin, Ltd.

Kroeber, A. L. (1939) Cultural and Natural Areas of Native North America. Berkeley: University of California Publications in American Archaeology and Ethnology, Vol. 38.

Rambo, A. Terry, (1984). An Introduction Human Ecology research on agricultural systems in Southeast Asia. East-West Environment and Policy Institute an Uniuversity of the Philipines at Los Banos.

Sudibyakto, (2010). Perubahan iklim Di Indonesia, Konsep: Adaptasi dan Mitigasi Dampak, University Gadjah Mada, Jogyakarta.

Tettebba, (2008). Panduan tentang Perubahan Iklim dan Masyarakat Adat, Victorya Taulia - Corfus (Editor). Indigenous peoples International Centre for Policy Research and Education, Philippines

Thomas, F. (1925). The Environmental Basis of Society: A Study in the History of Sociological Theory. New York: The Century Co. 